\title{
Identification of Educational Models That Encourage Business Participation in Higher Education Institutions
}

\author{
Angela Medina ${ }^{1}\left(\mathbb{D}\right.$, Jesus C. Hernández ${ }^{1, *(\mathbb{D}}$, Emilio Muñoz-Cerón ${ }^{2} \mathbb{D}$ and Catalina Rus-Casas ${ }^{3}$ \\ 1 Department of Electrical Engineering, The Jaén School of Engineering, University of Jaén, 23071 Jaen, Spain; \\ aquesada@ujaen.es \\ 2 Department of Graphic Engineering, Design and Projects, The Jaén School of Engineering, University of Jaén, \\ 23071 Jaén, Spain; emunoz@ujaen.es \\ 3 Department of Electronic Engineering and Automation, The Jaén School of Engineering, University of Jaén, \\ 23071 Jaén, Spain; crus@ujaen.es \\ * Correspondence: jcasa@ujaen.es; Tel.: +34-953-21-24-63
}

Received: 1 September 2020; Accepted: 9 October 2020; Published: 13 October 2020

\begin{abstract}
In a scenario in which the labour market is increasingly competitive and there is a need to provide students with practical training, Higher Education Institutions (HEIs) must promote the labour integration of students, by building their competences and shaping their skills in accordance with the strategic plans of companies. In the past, cooperation between companies and universities was based on informal agreements. Nowadays, companies are actively involved in the development of educational models. This is not only part of their corporate social responsibility, but also represents a business opportunity. In this context, the research performed to identify collaboration models between companies and HEIs that simplify the integration of training processes in companies is scarce. Therefore, the aim of this research is to identify existing joint educational models between companies and HEIs and to propose a methodology that allows them to select the models most in line with their business. The methodology applies a multi-criteria selection procedure and, in a simple way, enables the businesses to identify how to increase their involvement. Model identification is based on a proposal of common features that uses indicators for involvement quantification. This study selected ten HEI-company cooperation models and subsequently applied the Analytical Hierarchy Process (AHP) method to analyse the level of involvement that these models require of companies. Five models of different involvement levels were selected and detailed by their features.
\end{abstract}

Keywords: higher education institution; engineering studies; university-industry collaboration; applied educational models; companies

\section{Introduction}

In an increasingly competitive labour market, the identification of new educational models at Higher Education Institutions (HEIs) is necessary to foster the labour integration of university students. Such models benefit both the students and the industry, since they shape a company's prospective employees according to their technical and business plans [1-3].

Although for the last hundred years, there has been a close cooperation between universities and the industry [4], the context has changed considerably because of the emergence of a global knowledge economy. Today's scenarios now require strategic partnerships that greatly differ from individual research projects or summer internships [5,6], formerly used by HEI and the industry to devise programmes to promote student employability. 
The need to train students, who will be future professionals, has given rise to new educational models, such as the extended Problem-Based Learning (PBL) methodology [7-9]. However, deep insight is needed to evaluate the implication of companies in those educational models [10]. Another methodology is Work-Integrated Learning (WIL) [11], whose most widespread types are cooperative education, internships, apprenticeships, field experience or mandatory professional practice. In all of these models, HEI-company collaboration arises as a university initiative because such collaborations have traditionally been an effective way to provide students with work experience in their chosen career path while they are studying [12]. However, it is necessary to analyse the initiatives that start from companies and which have an impact on the academic and professional development of students.

For companies, in their role as training providers, these theories are of vital importance, particularly those based on Early Organizational Involvement (EOI), Recognition of Prior Learning (RPL), Work-Related Learning (WRL) and collaboration schemes, all amply reflected in the literature.

The EOI theory [13] comes from the literature specialized in supply chain theory through "Early Supply Integration" (ESI). The basic premise of ESI is that suppliers and buyers should work together to facilitate product development. Similarly, the EOI method, as applied to educational models, encourages HEIs and the industry to work together and become strategically involved in the professional development of students as a way to prepare them for the transition from university to the workplace. This idea is related to the methods based on Recognition of Prior Learning (RPL) [14,15]. It is widely acknowledged that embedding WRL programmes into HEI is a better way to prepare students and realistically shape their expectations regarding the workplace. This is conducive to greater retention and improved outcomes for graduates in their first job. All stakeholders are mutually benefited. Various studies show that there is a need to analyse learning in employment sectors [16], particularly in regard to continuing professional development and work placements [17].

The former programme, called Life Long Learning Programme, was launched in [18], with the JAMK University of Applied Sciences leading the initiative. The project showed that students, HEI experts and companies benefit from cooperation and that there is unused potential in this type of cooperation. The Life Long Learning Programme detected the necessity to identify educational models close to the industry. This project arose as a real-life problem-solving process where student groups solved real problems of companies in the field of Mechanical Engineering.

The programme gave rise to the Erasmus+ Project titled "Smart HEI-Business collaboration for skills and competitiveness" (HEIBus). The objective of the HEIBus Project (2017-2019) was to solve real-life industry problems proposed by the companies' partners through tasks in which students, experts from five HEIs and partners from seven companies from five countries actively collaborated (Jyväskylä University of Applied Sciences, Finland, Hochschule Esslingen University of Applied Sciences-Germany, Technical University of Cluj-Napoca-Romania, University of Jaén-Spain, and University of Miskolc-Hungary) [19], with the purpose of enhancing the cooperation between companies and HEIs, at the student and expert level, to encourage an entrepreneurial mindset.

The project built a fruitful cooperation between HEIs and companies, provided the companies with a wider perspective on potential solutions and promoted new innovations. During the 2017-2019 period, the University of Jaén-Spain and some local companies participated in the HEIBus project. In this framework, the HEIBus project developed and piloted three different cooperation processes that provided cooperation opportunities to match the different needs of companies:

- Multidisciplinary Real-Life Problem-Solving (RLPS) by students

- Expert Level RLPS by experts

- Flexible student mentoring by companies (Flex Mentoring)

This was the starting point to carry out a specific review of these cooperation processes. So, in multidisciplinary RLPS, teams of students are given a real-life problem (RLP) by a selected company. The student teams compete against each other to solve the problem. At the student level, this action supports certain initiatives promoted by the European Commission $[20,21]$ to enhance the education system and facilitate the entry of students into the labour market. At the company level, 
this supports the initiative innovation union [22] by promoting new research and innovations and helping new ideas to be transformed into products and services.

Expert level RLPS is similar to the method described above, but in this case the problem solving is performed by university experts. The expert promotes innovation and knowledge transfer and increases the skills of HEI experts in work-life problem solving, which can have an impact on the teaching methodologies used with their students. It also brings together a set of real problems that require innovative solutions.

Flexible student mentoring by companies (Flex Mentoring) is a set of methods to involve companies in the education at HEIs. Each company has a student group to mentor during the study period of the group. This enables the company to stay in touch with the student group to a greater or lesser degree, depending on the resources that they are able to invest.

Once again, the best practices of HEI-company cooperation were reviewed. Different educational models were identified, grouped and analysed and an initial classification was made, according to the following list:

- Student-company cooperation models

- HEI experts-company cooperation models

- Virtual coaching

- Company involvement in HEI education

Many education models focus on student-company cooperation models that start from the university site and progress towards the company. The positive effects for HEIs are well known, such as attracting external funding, increasing the quality of the educational programme and its reputation, assessments by both the representatives of companies and HEI academic tutors, engaging students in enterprise and increasing hands-on experience, among others. However, our research focuses on identifying models that start from the company site to the HEI site. Therefore, the novelty of this research was to give companies a clearer view of the characteristics of these models, as well as to identify both the level of demand made on them and the possible benefits they could obtain from applying these models. For this purpose, a set of common features was proposed that allowed for the identification and categorization of different HEI-company collaboration models and enabled involvement quantification by using indicators.

These indicators were defined during our HEIBus project collaboration period for all stakeholders. Indicators offer quantitative and qualitative information regarding the level of success of collaborations [23]. From the point of view of the companies, the most relevant indicators were the use of company equipment, growth rate, number of internships, industrial $\mathrm{PhD}$, competition and awards, number of lectures, tech-talks and mentoring programmes, among others. For HEIs, the key indicators were the number of joint labs, number of student applications and number of enrolled students, among others. Finally, the main indicators for students were the average salary, the time between graduation and working and the credits passed per academic year, among others.

So, the previous considerations and information allowed us to perform a ranking of the collaboration models by applying the Analytical Hierarchy Process (AHP) method. This method uses a multi-criteria selection procedure to identify and classify the involvement level of companies taking into account the prominence of the students. Information from a survey provided data from different stakeholders involved in the HEIBus project to apply the multi-criteria selection procedure on ten pre-screened collaboration models. Based on the results of the above procedure, five of these models were selected for a more in-depth analysis, i.e., the exhaustive description of features. The selection covered models with low levels of company involvement and models where the companies play a main role, and thus have a high level of involvement.

The document is organized as follows. Section 2 describes the methodology implemented for this study. According to the literature review and the HEIBus project objectives, different categories of HEI-company cooperation models and their characterization are presented. In addition, the AHP-based multi-criteria selection procedure is detailed for the model quantification considering the indicators, 
allowing us to carry out a model ranking. Results are presented in Section 3. Firstly, a pre-screening of ten collaboration models with a more in-depth feature description was done, and then the results of the multi-criteria procedure applied to these models were discussed. The focus was on the model ranking procedure in which the level of company involvement in each model is disclosed by providing a detailed description that covers the whole spectrum of involvement levels. Finally, Section 4 presents the conclusions that can be derived from this research.

\section{Methodology}

This section first identifies and classifies different categories of HEI-company cooperation models by grouping educational models that share a series of similar characteristics and features. The following step is the description of the multi-criteria selection procedure followed to rank the selected educational models according to the involvement level of the companies with respect to the integral development of the student.

\subsection{Categories of HEI-Company Collaboration Models}

This section discusses and classifies different categories of HEI-company cooperation models based on educational or real-life work. A set of common features, including their brief description, is defined. This allows identifying and categorizing the models and uses indicators to quantify the involvement level. These features are then comprehensively specified for each model category to carry out their detailed characterization in Section 2.1.1, Section 2.1.2, Section 2.1.3, Section 2.1.4. Finally, Section 2.1.5 highlights the main similarities and differences between categories.

The definition of HEI-company cooperation models is far from clear in regard to the scope and pattern of collaboration [24], and mapping out patterns of collaboration is known for being complex [25].

In this context, instead of comparing and evaluating collaborative models, regardless of their origin, our classification of categories aims to analyse industry-based models that target HEIs rather than programmes proposed by universities.

Many of the models in the literature are intended as guides for practitioners based on the analysis of different case studies linked to the open innovation concept. They demonstrate that patterns of collaboration are complex and involve many closely related activities, such as consultancy services, researcher and staff mobility, technology transfer, commercialization, research parks and a host of activities directed towards students.

A common way of classifying university-business links is to look at the main content of the activities that a particular collaboration is focused on. Usually, the activities lead to different results and produce different short- and long-term effects for the partners involved in terms of the experiences, competences and networks that are developed through the collaborative relationships. These effects are beneficial for future collaborations between the parties.

A systematic review of the research literature through journal databases and websites is entirely necessary [26] and would help companies identify gaps and determine best practices for managing collaboration through relevant patterns. Therefore, our proposed classification of the HEI-company cooperation model categories is based on a systematic review. The reviewed educational models are usually followed by a large number of universities that have a long tradition of cooperating with companies, such as institutions in Germany, Norway and Denmark, in Europe, and universities in the USA, Canada and Australia. Other geographical areas have not been included in the review, since their models have been inherited from European, Canadian or American universities.

The proposed categorization of the educational models is based on the definition of a series of features applicable to any educational model. The qualitative, quantitative, contextual, organizational and other diverse information obtained by applying the features to each HEI-company collaboration model category allowed us to classify the selected models according to a series of common characteristics. The collaboration models in our systematic review could be classified into four categories, considering the educational or real-life working processes and location (company or HEI site) [27]: 
1. Models based on Joint Educational Programmes (JEPs).

2. Models based on Real-Life Teaching-Learning Processes (RLTLPs)

3. Models based on Approaches of Working Life to Students (AWL2Ss)

4. Models based on Sponsorship Initiatives by Companies (SICs).

Table 1 identifies the main differentiating characteristics of each model category. In the following subsections, each of the characteristics in this table will be placed in the context of each category.

Table 1. Identification of common features of the higher education institution (HEI)-company collaboration model categories.

\begin{tabular}{|c|c|}
\hline Features & Definition/Explanation \\
\hline \multirow{8}{*}{$\begin{array}{l}\text { Main } \\
\text { educational } \\
\text { purposes }\end{array}$} & $\begin{array}{l}\text { It refers to the goals related to learning, teaching, training, research and development } \\
\text { concepts. They are designed jointly by the HEIs and the companies, although the latter are } \\
\text { responsible for their supervision. } \\
\text { The following concepts, tasks or skills are developed and fostered depending on the } \\
\text { proposed classification: } \\
\text { Models based on JEPs: }\end{array}$ \\
\hline & $\begin{array}{l}\text { Curriculum and strategies to facilitate industry participation, viable objectives, an open } \\
\text { system, effective human interaction, in-house processes, theory-practice integration in } \\
\text { work placement and the gradual acquisition of skills. }\end{array}$ \\
\hline & Models based on RLTLPs: \\
\hline & $\begin{array}{l}\text { Theory-practice integration, personal evolution, career advancement and expansion, } \\
\text { professional socialization. }\end{array}$ \\
\hline & Models based on AWL2Ss: \\
\hline & $\begin{array}{l}\text { Development of transversal skills, such as CV design, personal interviews, ability to work } \\
\text { in a team and adaptability to new situations; improved social skills and ability to transfer } \\
\text { practical knowledge and implement it locally. }\end{array}$ \\
\hline & Models based on SICs: \\
\hline & $\begin{array}{l}\text { Enhancement of students' skills applied to company strategies and contribution to the } \\
\text { convergence of R\&D in the HEI and industry. }\end{array}$ \\
\hline $\begin{array}{l}\text { Role of the } \\
\text { parties } \\
\text { involved }\end{array}$ & $\begin{array}{l}\text { The responsibility, role and level of commitment of the different parties involved in the } \\
\text { training process proposed by the companies and HEIs and which has a direct impact on } \\
\text { the students. }\end{array}$ \\
\hline $\begin{array}{l}\text { Incentives of } \\
\text { the parties } \\
\text { involved }\end{array}$ & $\begin{array}{l}\text { HEI incentives are focused on improving the learning process of students and providing } \\
\text { high-quality degrees in which students solve real-life problems, whereas, depending on } \\
\text { the model, the company seeks to incorporate students, adapted to their needs, into its } \\
\text { business. Student incentives are associated with more optimized work placement and } \\
\text { higher employability rates. }\end{array}$ \\
\hline Duration & $\begin{array}{l}\text { It refers to the time span of the collaboration. Students would work full- or part-time, or } \\
\text { there could be one or several work periods during their training. }\end{array}$ \\
\hline $\begin{array}{l}\text { Obligatory } \\
\text { nature }\end{array}$ & $\begin{array}{l}\text { It refers to whether the proposed educational models are chosen optionally by the student } \\
\text { or, on the contrary, whether they are included in the higher education curriculum as a } \\
\text { compulsory task to be carried out. }\end{array}$ \\
\hline $\begin{array}{l}\text { Monetary } \\
\text { compensation }\end{array}$ & $\begin{array}{l}\text { It indicates whether there is any salary or payment for the students involved in a certain } \\
\text { type of training action. }\end{array}$ \\
\hline $\begin{array}{l}\text { Territorial } \\
\text { scope }\end{array}$ & It designates the geographical area of influence and applicability of this model. \\
\hline $\begin{array}{l}\text { Additional } \\
\text { supporter }\end{array}$ & $\begin{array}{l}\text { This refers to whether there is an external body that finances or sponsors this educational } \\
\text { model, regardless of whether the company contributes with its own capital and the } \\
\text { university with part of its budget. It helps to mitigate barriers among both organizations. }\end{array}$ \\
\hline $\begin{array}{l}\text { Legal HEI } \\
\text { status }\end{array}$ & to whether the universities are public or private. \\
\hline
\end{tabular}




\subsubsection{Collaborations Focused on Joint Educational Programmes (JEPs)}

The models included in this category of collaboration combine traditional master classes with practical work experience. However, it is necessary to bear in mind that the initial proposal for such actions comes from the industry and is adapted to the curricular design of the studies. These models thus focus on the course structure and the curriculum.

Collaborations can take place at different geographical levels, from international industry associations to local companies. Students can either work full-time with alternating periods of work and college or they can work part-time by combining their work and academic studies. They can always work at the same company or in different ones. This sort of collaboration usually involves at least a one-year extension of college.

The educational models found in the methodological review, which may be included within this category, share the indicators listed in Appendix A, Table A1.

2.1.2. Collaborations Based on Real-Life Teaching-Learning Processes (RLTLPs)

A typical example is a visiting lecturer (VP) (see Appendix A, Table A2) who occasionally participates in regular teaching. It also refers to companies that provide definitions for student research projects in doctoral programmes. Other examples are summer schools, which allow for the possibility of increasing the international, national or local impact of the industry.

\subsubsection{Collaborations Focused on Approaches of Working Life to Students (AWL2Ss)}

Although the models included in this category (see Appendix A, Table A3) can be somehow associated with the development or modification of the educational programmes described previously, their main objective focuses more on providing information for existing working opportunities and a work context than being actively involved in the educational process of students. The students need to discern how to shape their educational process depending on the context and scenarios offered by the companies.

Typical examples are Job Fairs and recruitment programmes. Other important initiatives are job counselling, industrial mentoring, short project contracts, competitions and awards.

\subsubsection{Collaborations Based on Sponsorship Initiatives by Companies (SICs)}

This category of model (see Appendix A, Table A4) is based on actively encouraging and attracting talent. Additionally, its objective is not only to collaborate with the research lines of the universities, but also to define its own research lines to be carried out by HEIs that favour the business lines of the companies.

Common collaborations are student grants and scholarships to attract and recruit talent. Other initiatives include joint labs or technological parks at HEIs for high-impact R\&D.

\subsubsection{Comparison of the HEI-Company Cooperation Model Categories}

From the point of view of educational purposes, models based on JEPs focus on the revision of existing programmes through industrial advisory boards (IAB) (usually at the national or regional levels). These models have the opportunity to benefit from the expertise of the HEIs and adapt the students' curriculum to better fit their business needs, whereas models based on RLTLPs have company experts act as visiting professors, providing realistic, novel and updated practical concepts into the theoretical class sessions. In addition, companies provide guidance for students' research projects and the use of their facilities or real-life business cases on an international, regional or local level. For companies, important incentives are the access to highly skilled workers and specialized research laboratories or project start-ups in HEIs.

The other models based on AWL2Ss focus more on providing information for existing work opportunities. The work context includes voluntary internships, participation in career fairs, industrial 
mentoring and competitions. For companies, disseminating their activities and business lines is a challenge and can influence students' decision making based on the company's work needs.

Finally, models based on SICs focus on actively encouraging and attracting talent through actions like student grants and scholarships. Other initiatives include joint labs or technological parks at HEIs for high-impact R\&D. Here, the company's incentive is a better and higher number of trained workers according to the realistic needs of their companies.

Models based on JEPs and RLTLPs show some similarities, considering that companies' representatives are involved in the pure learning processes. On the other hand, models based on AWL2Ss and SICs are focused on the company's own site and the need to get students prepared for real working life.

From the perspective of students' incentives, all the models provide great advantages. The differences are that the first three models are developed during the students' academic period, within the university context. The models based on SICs offer them the option of continuing their studies in a highly specialized work environment in line with company interests and future job insertion.

Other similarities and/or differences refer to the duration and scope of the proposed actions.

\subsection{Multi-Criteria Selection Procedure: AHP Method}

The following is a description of the multi-criteria selection procedure proposed to rank the selected educational models according to the involvement level of the companies. This procedure allowed us to categorize the list of HEI-company collaboration models according to the level of intensity of their involvement, ranging from low to high. The involvement level was based on the following criteria:

- Students work instead of being mere observers

- Students obtain some type of payment for their labour

- The progress of students is checked by the university or the company

- A company employee evaluates student performance

To assign a level of intensity to each of the educational models, the multi-criteria selection procedure in Figure 1 was proposed based on the AHP method [28].
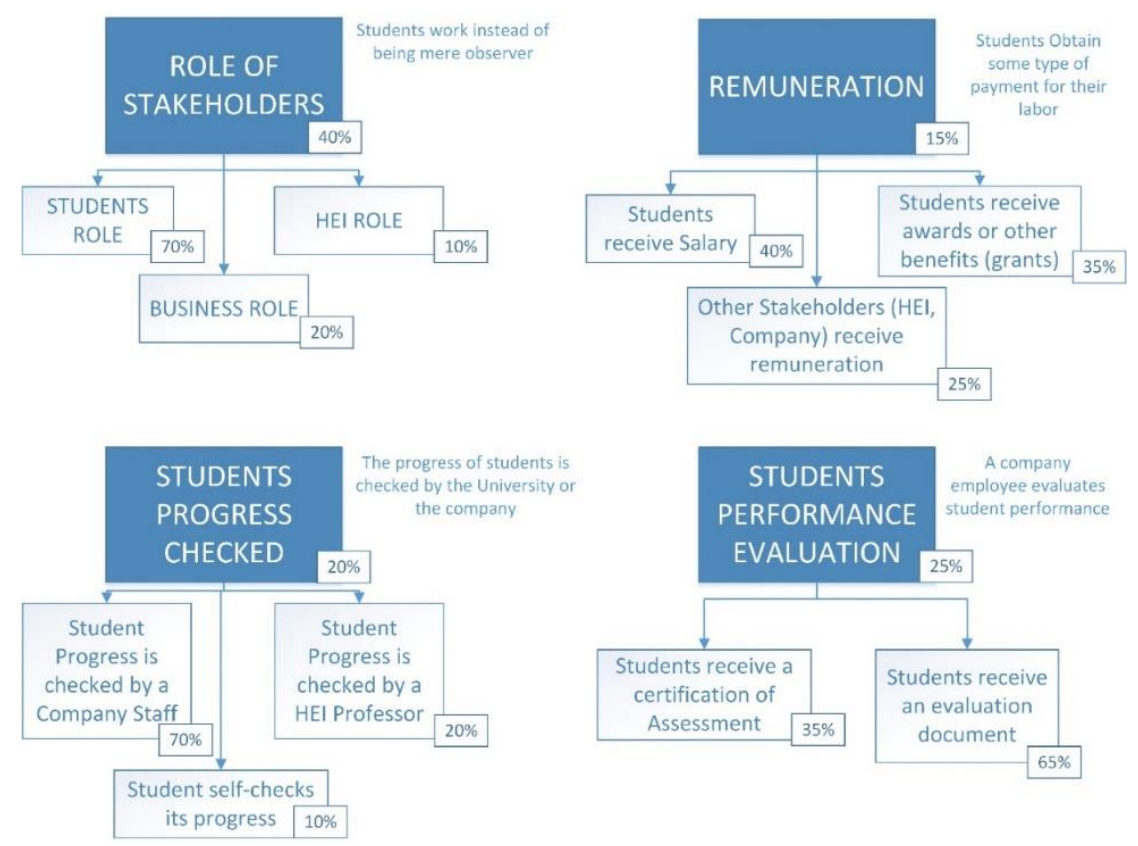

Figure 1. Weighting of model categorization according to the analytical hierarchy process (AHP)-based multi-criteria selection procedure. 
Each of the proposed criteria was assigned a specific weight. A series of sub-criteria were defined for each of them, with a determined weight, favouring at all times those criteria that benefit the development of the student.

Defining the involvement levels of the companies was the result of a survey given to different interested stakeholders. The questions included in the survey for each sub-criteria listed in Figure 1 were related to the indicators that affect each of the stakeholders involved, i.e., HEIs, companies and students, and qualify the involvement level of the companies in each of the identified educational models. We received 72 answers from eight different countries (Figure 2). Survey questions and the statistical median of the selected values were used to determine the weights.

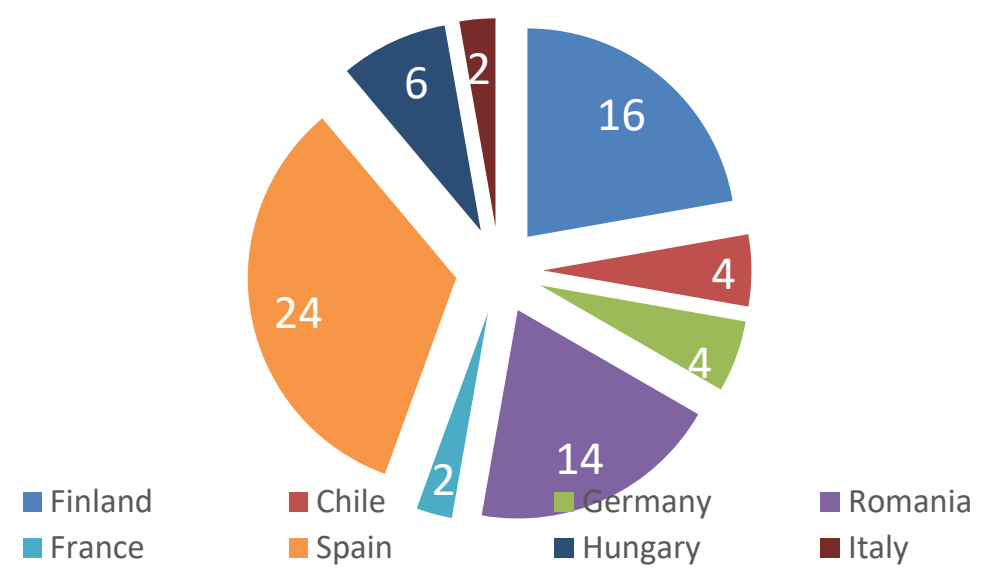

Figure 2. The amount of stakeholders who filled out the survey classified by their origin country.

\section{Results and Discussion}

Based on the criteria and features identified in the Methodology Section, Section 3.1 shows the results of the classification of HEI-company collaboration models. Of the models found, only the most representative were selected, since they had the main characteristics described for each model in each category. Then, in Section 3.2, the AHP-based multi-criteria selection procedure is applied to analyse the level of involvement that the models require of the companies.

\subsection{Preliminary Classification and Identification of Models}

Despite the numerous collaboration examples found, only those whose direction was from companies to HEIs were selected. Based on their main features, the most representative models were categorized and at least one university (country) was identified as an example of its implementation.

\subsubsection{Classification Results on Collaboration Models Based on JEPs}

This is one of the most common cooperation model categories between HEIs and companies. There are many universities that opt for this collaboration model category, but only the two most representative ones, which arise from the initiative of the industry site, were identified. They are the following:

\section{- Model 1 (M\#1): Industrial advisory boards (IABs)}

An Industrial Advisory Council is normally an independent body that advises and supports the decision making of the heads of departments or faculties through mutual feedback, with the aim of continuously fostering relations between the business world and the university [29,30]. Its main objectives include the advice and recommendation of the content and development of the knowledge areas of knowledge in the curriculum of a certain academic degree. It promotes the discussion of strategies designed to encourage the involvement of the business sector in the preparation and adaptation of existing curricula or the proposal of new academic programmes adapted to the industrial 
reality in the immediate context. It also provides advice concerning curricular issues and ensures that the courses offered by universities facilitate access to the profession chosen by future HEI graduates. Therefore, it helps with the planning, updating and academic accreditation of the degrees offered by the universities. Apart from purely academic topics, it also provides information regarding the research lines of the $R \& D$ groups that are useful to the industry they represent and bring together. It is customary for engineering education programmes to make use of a voluntary IAB for aid and advice [31]. There are many examples of universities following this model [32-34]. The University of Oklahoma could be considered as an example due to its effective implementation of the model [35]. However, in order to assess the effectiveness of the IAB, there should be a mechanism that guarantees the quality of the cooperation agreements or the university degree accreditation. For example, in the USA, the Accreditation Board for Engineering and Technology (ABET) has obliged many colleges to create or regenerate new industrial advisory boards on their campuses [36,37].

\section{- Model 2 (M\#2): Dual vocational education training (Dual VET)}

A dual education system combines practical apprenticeship in a company and specialized theoretical courses in a university with a clear orientation towards professional training [38]. This type of system envisages alternating periods of HEI education and practical training in an industrial environment. The company is thus responsible for ensuring that students receive the competences in the training descriptions for each degree $[39,40]$. In this sense, the theoretical classes have to be adapted to the requirements that companies need and are going to provide to the students. These companies provide a tutor responsible for the continuous follow-up of the students and additional theoretical training. This system is widespread in several countries in central and northern Europe, though mainly in Germany, where this system first emerged in 1969. After its improvement in 2005, it spread rapidly and became standardized throughout the country. It is an opportunity for government administration, since it promotes cohesion between the state, private companies, trade unions and universities. The Danish model highlighted in [41] combines the positive aspects of the German dual apprenticeship systems with the Nordic school-based models. This model has also been adopted by some American institutions [42].

\subsubsection{Classification Results on Collaboration Models Based on RLTLPs}

In this category, three models have stood out for their impact on the educational processes of students.

\section{- Model 3 (M\#3): Visiting professors (VPs)}

External experienced speakers from the industry give lectures at the HEI related to the content of a certain degree. These can be scheduled lectures, research seminars or advanced technical talks that complement regular sessions [43]. This model also envisages short-term contracts for specific project secondments or guest lectures. Accordingly, a part-time professor acts as a short-term secondment for company staff within HEIs. This industry-to-university resourcefulness uses the experience of VPs to expand the students' knowledge and increase their employability and skills. VPs generally have more contact with undergraduate students studying for a BEng (3-year programme) or a MEng (4-year programme), but may also teach in the MSc programmes and modules. This model is implemented in the UK, in the Royal Academy of Engineering (RAEng) [44].

\section{- $\quad$ Model 4 (M\#4): Summer schools}

This cooperation model fosters the students' competences and gives them a space outside of the schoolroom, where they can acquire multidisciplinary skills related to the professional world. They can also complement their academic training, while at the same time cultivating a portfolio of contacts that can be of great use to them in their future professional development [45]. The summer schools in this 
model are different from conventional university summer courses (e.g., lifelong-learning activities) because they are based on a Project-Based Learning (PBL) philosophy, which combines research and industrial activities [46]. Nowadays, PBL methodology is a very extended and consolidated cooperation model, and there is a wide course offer within the European Union [47]. In certain aspects, this model is very similar to internships in companies and workshops at tech-talks as well. The model we will analyse is the one in the Engineering College of Aarhus (Denmark) [48].

\section{- Model 5 (M\#5): Industrial PhD programmes}

It is increasingly common for students to wish to continue their education after completion of undergraduate and master's programmes. As an alternative to another type of master's degree, there is research training, which takes the form of studies leading to a doctorate degree [49]. Unlike traditional theses, for those cases in which one does not want to lose the perspective of the applicability of R\&D lines beyond the merely academic, industrial doctoral programmes arise where companies hire $\mathrm{PhD}$ students and create what is known as Industrial PhD programmes, even though companies could increase the training capacity of their own employees [50-52]. The report about doctoral education [53] underlines that collaborative $\mathrm{PhD}$ programmes established between universities and industry are becoming increasingly important across Europe. It highlights that both universities and businesses consider collaborative doctoral programmes as important channels for supporting both innovation and recruitment efforts. Among the models found, the Danish Industrial PhD Programme is highlighted [54].

\subsubsection{Classification Results on Collaboration Models Based on AWL2Ss}

Based on the key indicators described in Table A3, the most representative collaboration models for the knowledge transfer between studies and work life are selected and summarized below:

\section{- Model 6 (M\#6): Career fairs}

Many universities hold annual employment fairs that give students a valuable opportunity to meet companies interested in hiring them. Such fairs usually last from one to three days. Many employers attend these events to increase their campus visibility, to explain the benefits of working in their company and to inform students about entry-level jobs, co-op chances and internships. From the student's perspective, it is an opportunity to learn first-hand about the latest employment trends $[55,56]$.

Many of these companies also organize on-campus recruiting programmes and use the career fair as a kick-off for their recruiting season. Sometimes the aim is only to introduce students to their organization and collect resumes for future openings [57]. Participation in career fairs allows companies to meet face-to-face with students interested in their organization. At the same time, it raises the companies' profile, as they also gain excellent exposure for their brand [58]. This model is followed by universities from all over the world. Furthermore, there are universities, like the University of Malaga, that it is offering the same activity but inside a virtual environment $[59,60]$.

\section{- Model 7 (M\#7): Industrial mentoring programmes}

These types of programme are based on mentoring, with experienced people (usually representatives of local companies) striving to help a student (mentee) enhance their skills, to strategically manage their career and to achieve important professional goals [61,62].

Reference [63] defines an informal mentor as someone who provides coaching, listening, advice, sounding board reactions or other help in an unstructured, casual manner. In contrast, a formal mentor has an ongoing, planned partnership with the mentee that focuses on helping him/her reach specific academic and professional goals. In other cases, mentorship is often offered directly by companies as a core value [64-67]. Many professional development opportunities provide a mentor to grow students' career skills. An example is the model followed by the King's College London and the University of Manchester $[68,69]$. They recommend that the mentors be only alumni or PhD students. 


\section{- Model 8 (M\#8): Competitions and awards}

In this model, companies either encourage students with awards or fund a competition in which HEI teams compete with each other to develop a certain product by following certain rules [70]. This sort of model enhances the motivation of the students involved [71-73].

Moreover, economic incentives also play an important role in the learning procedure of the HEI participants $[70,71]$. Because teams work together to solve a certain problem, this model bears a certain resemblance to Project-Based Learning (PBL). Consequently, certain authors refer to this model as Competition-Based Learning methodology [74]. This cooperation model is firmly established in the field of robotics [75], but the latest trends show that this model also has a great acceptance in the energy [76] and automotive [77] sectors.

\subsubsection{Classification Results on Collaboration Models Based on SICs}

Although this is a very frequent form of cooperation, it usually overlaps with any of the models described in the previous categories. Therefore, in this section, only the cases involving a direct disbursement focused on a particular educational or research target are collected.

\section{- Model 9 (M\#9): Student grants and/or scholarships}

Grants and scholarships are usually awarded based on a student's academic performance and achievement as well as on his/her financial needs. Given this scenario, there are companies that provide financial aid to students so that they will be eligible for certain HEI courses through grants and scholarships which do not need to be repaid. In return, the student not only must obtain certain qualifications, but also work in the company or agree to join the company after graduation.

In this way, companies can attract qualified talent. Other organizations are focused on certain groups of students such as students engaged in science, technology, engineering and mathematics (STEM) education [78] or minorities (ethnic heritage, gender, people with a disability, etc.) [79] for awarding scholarships. Additionally, some companies also provide scholarships to their employees' relatives [80].

\section{- Model 10 (M\#10): Sponsorship of joint laboratories at HEIs}

This model focuses on the sponsorship of R\&D laboratories at the HEI campus for research projects. This support involves building a comprehensive R\&D facility, paying for apparatus, hiring researchers for these laboratories or merely providing a regular monetary contribution [81,82].

Normally, this cooperation model is focused on R\&D lines linked to the company's strategy and product portfolio, or merely on marketing purposes $[83,84]$. One difference of this model is the funding or sponsorship of R\&D projects within the sphere of interest of the company. Although it does not directly imply the sponsorship of a physical location, it may contribute to enhancing the potential of already established HEI laboratories $[85,86]$. The model analysed is the Tech Lane Ghent Science Park in Belgium.

\subsection{Selection of Models According to the Involvement Level of the Companies}

As a result of applying the AHP-based multi-criteria selection procedure described in Section 2.2, the level of company involvement for each of the selected models was identified, as shown in Table 2. 
Table 2. Level of involvement and selection of models.

\begin{tabular}{|c|c|c|c|c|c|}
\hline \multirow[b]{2}{*}{ Model } & \multicolumn{5}{|c|}{ Features } \\
\hline & $\begin{array}{l}\text { Model } \\
\text { Category }\end{array}$ & Model Name & $\begin{array}{l}\text { Location of the } \\
\text { Selected } \\
\text { Example }\end{array}$ & \multicolumn{2}{|c|}{$\begin{array}{l}\text { Involvement Level for } \\
\text { Companies }\end{array}$} \\
\hline M\#1 & \multirow{2}{*}{ JEP } & $\begin{array}{c}\text { Industrial } \\
\text { advisor boards }\end{array}$ & United States & 19 & Low \\
\hline M\#2 & & Dual VET & Denmark & 81.7 & High \\
\hline $\mathrm{M \# 3}$ & \multirow{3}{*}{ RLTLP } & $\begin{array}{l}\text { Visiting } \\
\text { professor }\end{array}$ & UK & 54.4 & Middle \\
\hline $\mathrm{M \# 4}$ & & $\begin{array}{l}\text { Summer } \\
\text { schools }\end{array}$ & Denmark & 46.9 & Low-Middle \\
\hline M\#5 & & $\begin{array}{l}\text { Industrial PhD } \\
\text { programmes }\end{array}$ & Denmark & 68.2 & Middle-High \\
\hline M\#6 & \multirow{3}{*}{ AWL2S } & Career fairs & United States & 51.6 & Middle \\
\hline M\#7 & & $\begin{array}{c}\text { Industrial } \\
\text { mentoring } \\
\text { programmes }\end{array}$ & UK & 83.6 & High \\
\hline M\#8 & & $\begin{array}{l}\text { Competition } \\
\text { and awards }\end{array}$ & Spain & 67.8 & Middle-High \\
\hline M\#9 & \multirow[t]{2}{*}{ SICs } & $\begin{array}{c}\text { Student } \\
\text { grants/scholarships }\end{array}$ & $\begin{array}{c}\text { United } \\
\text { s States/Spain }\end{array}$ & 41.1 & Low-Middle \\
\hline $\mathrm{M \# 10}$ & & Sponsorship & Belgium & 72.2 & Middle-High \\
\hline
\end{tabular}

The low level corresponds to an intensity of involvement below 30, while a low-middle level ranges from 31 to 50 . On the contrary, for a model to fall within a middle level, it must have reached a score between 51 and 60, and for a middle-high level, between 61 and 80 . Finally, the high level of involvement is reserved for those models with a score greater than 81 out of 100 .

Among all the models analysed, five educational models were selected that are representative of each level: high, middle-high, middle, low-middle and low. The objective is to deepen the understanding of the existing differences among them by considering the level of implication for the companies as well as the role of the students. Therefore, an in-depth analysis of their features is detailed below.

\section{- Model 1 (M\#1): Industrial advisory boards (IABs)}

For M\#1, the initiative is usually co-promoted by the company and the HEI. In addition, the companies act as advisors and supervisors (see Table A1), while the HEIs provide the workplace and a contract with the persons involved. The role of the students does not require active involvement. The incentives for all involved parties are detailed below. For the companies, the incentives are as follows:

- Inform the HEI of the optimal skill-set sought in new employees

- Play a civic and educational role in the community

- Establish collaborations in projects that can be of direct benefit to the company

- Enhance professional credibility

- $\quad$ Provide advice in regard to curriculum design

For the HEIs, the incentives are promoting the importance of the academic institution in the community as well as implementing direct corporate contributions towards the infrastructure of some educational programmes. In addition, the main incentive for students is the opportunity for full-time employment or an internship.

Regarding the duration, usually an IAB is involved throughout the whole formative period. While the IABs established are not obligatory in character, the requirements solicited by professional associations are mandatory. Both companies and HEIs pay the IABs. Their territorial scope can be 
international, national, regional or local, but in any case the location is within the HEI campuses. Other additional supporters of these IABs are labour or trade unions. Another feature to consider is that IABs can be implemented through public or private universities.

\section{- $\quad$ Model 3 (M\#3): Visiting professors (VPs)}

For $\mathrm{M} \# 3$, the role of the company is to act as a provider of senior industry practitioners or the company's experts who perform the following tasks:

- Inform the HEI of the optimal skill-set sought in new employees

- Actively teach and mentor students at the host university

- Contribute to teaching postgraduate courses

- Develop the curriculum (new modules/programmes and strategy design)

- Supervise students

- Perform activities such as industrial visits

- Propose and supervise undergraduate projects

On the other hand, the role of the HEI is to provide a letter of appointment and a formal contract of employment to the VPs (not necessarily paid). It provides them with the same resources that it puts in place for regular teachers. Students have the role of observers.

For the companies, the following incentives are desired:

- Direct and tangible access to the educational programmes

- Identify a highly skilled workforce

Meanwhile, the incentives for HEIs consist of bridging the training gap between academia and the industrial world. For students, the incentives are to know first-hand the reality of a business and to be a qualified professional.

The VPs are not necessarily involved during the whole formative period, and their character is optional. The monetary compensation depends on the HEI-Business agreement; usually, it is either an award or not paid. About the territorial scope, most frequently the company and HEI are accessible regionally or locally, but sometimes even nationally or internationally. HEIs with private legal status are better positioned for this model than public HEIs.

\section{- Model 4 (M\#4): Summer schools}

For M\#4, the company does not have a contract with the HEIs or the students, and there is no obligation for them to employ students when they graduate. The role of the company consists of:

- Explaining the company's guiding principles and mission, design, product portfolio, career paths, research initiatives and sales strategy

- Guiding students in the modelling of their projects and supplying them with feedback

- Providing students with a work environment and resources

Here, the role of HEIs is as follows:

- Student selection

- Party responsible for elaborating the programme and the teaching approach in line with the syllabus

- Student supervision

- Academic lectures on relevant topics

However, the role of students is based on the successful implementation and resolution of a PBL project within the context of an international multidisciplinary team.

The benefits for a company are derived from new ideas generated by students, enhanced recruitment potential and the inspiration that comes from working with motivated young people. For the HEI, it is an opportunity to promote their visibility and make it attractive to future students through its commitment to complementary practical training. For students, the incentives are the following: 
- Improve their practical skills and have a chance

- Carry out in a practical way what has been learned in the theoretical classes

Generally, the duration of these activities will be three-four weeks (on average), and the company is not involved during the whole formative period of the degree, only in this formative activity. The activities are voluntary, not paid and have a mainly international scope. An additional supporter is not necessary. Private universities are more likely to favour this type of model than public ones.

\section{- Model 7 (M\#7): Industrial mentoring programmes}

For M\#7, the role of the company consists of providing the mentors. These mentors have personal interaction with a student or team (face-to-face, by e-mail or on online platforms). They guide students in the right direction by indicating the best pathway to a solution within the context of a team instead of providing them with the answer. There are additional duties the mentor performs:

- Describe their experiences as industrial experts

- Provide career counselling and help in writing job applications and in recruitment

- Explain the toolsets used in their company as well as other organizations

In the case of graduate students, mentoring is an effective way to start off their career and help students to show off their talents.

The role of the HEI is as follows:

- Forge agreements with companies

- Provide a digitalized and/or paper booklet with information about the course, so that students can enrol in lectures, laboratory sessions, etc.

- Arrange for all students to have mentors and set up a schedule for meetings during the course

- Provide a site on campus with suitable infrastructure

- Increase the industrial relevance of the course by giving students access to an industry professional

- Actively recruit students by means of talent programmes and competitions

On the other hand, the role of students is the following:

- Actively participate by asking questions and proposing discussion topics

- Productively interact with members of the same team

- Take part in competitions and carry out a final project that reflects their personal skills, with potential for possible recruitment.

Assessing the company's incentives, we can report that they consist of the following:

- Advertise their company

- Create early relationships with students who may eventually become their employees

- Improve the quality of their workforce by actively following good practices from the very beginning

For the HEI, the main incentive will be to build awareness among their students of the working environment within their immediate context. For students, it is the access to coaching by an experienced person in an industrial sector of interest. These programmes do not extend necessarily throughout the whole formative period. Additionally, the participation is voluntary and usually unpaid, although some benefits need to be defined for the company staff involved in this action. Additional supporters are industrial and professional associations. The territorial scope is most frequently regional or local, and sometimes international or national. Finally, private companies can be more advanced in this model. 


\section{- Model 10 (M\#10): Sponsorship of joint laboratories at the HEI}

For the model M\#10, the company does not have a contract with the HEIs or the students, and there is no obligation for them to employ students when they graduate. The company's role is to integrate with HEI facilities and provide equipment for the HEI's installations. The role of the HEIs is the management of the science park and to act as incubators for the creation of start-ups. In addition, HEIs should be able to provide accommodation for laboratories and companies in their facilities. The role of students is passive.

The company's incentives consist of a direct access to available human resources (university students and researchers) and the collaboration with other companies with similar interests. For HEIs, it is the access to outside sources for research funding, whereas for students the incentives are to continue their studies in a research environment, but oriented to the needs of an enterprise.

This sponsorship's duration is a long-term agreement, its nature is usually voluntary and its territorial scope international. The monetary compensation depends on the sort of agreement, and often the government acts as an additional supporter of these HEIs (mainly public universities).

\section{Conclusions}

This research has identified existing joint educational models between HEIs and companies and has proposed a methodology, through the application of a multi-criteria selection procedure that allows them to select the models most in line with their businesses. This methodology provides a simple way for them to identify how to increase their involvement and the possible benefits they can obtain as a result of applying these models. This information provides companies with a clearer view of the characteristics of these models, allowing them to identify the level of demand made on them and the possible benefits they can obtain as a result of applying these models.

From a methodological point of view, different categories of HEI-company cooperation models were proposed, along with their characterization through a list of features, such as the main educational purposes that are desired, the role of the parties involved in the proposed model, the incentives of the parties involved and the duration of the cooperation, among others. Subsequently, an AHP-based multi-criteria selection procedure was modelled for the quantification of the ten identified models from indicators. A quantitative result for each mode was obtained and a ranking of the involvement level was performed for the considered collaboration models. Thus, a low level corresponds to a low intensity of involvement, below 30 points, while a high level of involvement is reserved for those models with a score greater than 81 points.

The research highlights the importance of training graduates in skills that prepare them to achieve the learning outcomes required by their careers. This is especially true in an increasingly competitive work life, where students should be able to adapt quickly and offer innovative and competitive solutions to the problems that arise. It is important to note that collaboration models between universities and the industry increase the students' work-relevant competences and skills, enhance their employability and facilitate the acquisition of entrepreneurial attitudes and mind-sets.

To summarize, the identification of these models allows a clear framework for collaboration. In addition, the identification of the models will facilitate the collaboration of companies in the practical training of graduates. Furthermore, the models will allow for a deeper integration of the company with the student groups throughout the collaborations and provide a good form of recruitment, which will undoubtedly be helpful to the companies in the long-term. Future work should investigate how the selected models in different settings impact student learning.

Author Contributions: Conceptualization, A.M., J.C.H., C.R.-C. and E.M.-C.; methodology, A.M. and J.C.H.; formal analysis, A.M. and J.C.H.; investigation, A.M. and E.M.-C.; resources, A.M., C.R.-C. and E.M.-C.; data curation, J.C.H.; writing - original draft preparation, A.M. and E.M.-C.; writing-review and editing, A.M., J.C.H. and E.M.-C.; visualization, A.M. and J.C.H.; supervision, A.M. and J.C.H.; project administration, A.M. and J.C.H. All authors have read and agreed to the published version of the manuscript. 
Funding: This work has been carried out in the framework of the project: "Smart HEI-Business collaboration for skills and competitiveness (HEIBUS)", which it is co-funded by the Erasmus+ Programme of the European Union (Project Index: 575660-EPP-1-2016-1-FI-EPPKA2-KA). The authors would like to thank the Jaen School of Engineering (University of Jaén, Spain) for supporting this research and contributing to create a network among students and business, concretely with local firms.

Conflicts of Interest: The authors declare no conflict of interest.

\section{Appendix A}

Table A1. Key features for the category of models based on joint educational programmes (JEPs).

\begin{tabular}{|c|c|}
\hline Feature & Description \\
\hline $\begin{array}{l}\text { Main } \\
\text { educational } \\
\text { purposes }\end{array}$ & $\begin{array}{l}\text { - Integration of theory and practice into an existing workplace } \\
\text { - Progressive acquisition of skills and competences adapted to the needs of the } \\
\text { labour market } \\
\text { - Curriculum development and strategies to foster industry participation } \\
\text { and implication } \\
\text { - Create a network of contacts }\end{array}$ \\
\hline $\begin{array}{l}\text { Role of } \\
\text { company }\end{array}$ & $\begin{array}{l}\text { Offer an apprenticeship contract for students (dual VET models) } \\
\text { Differentiating roles: } \\
\text { Advisor: suggestion of possible courses; master dissertation counselling; proposal of topic } \\
\text { for student research projects } \\
\text { Work-placement supervisor; board composed of senior executives with diverse } \\
\text { backgrounds, who are firmly committed to both the academic institution and the } \\
\text { profession: business committee whose role is to approve programmes }\end{array}$ \\
\hline Role of HEI & $\begin{array}{l}\text { - } \quad \text { Set learning objectives and approve host company sites } \\
\text { - } \quad \text { Curricular adaptation of existing studies to business recommendations } \\
\text { - } \quad \text { Assist the company with student selection } \\
\text { - } \quad \text { Monitoring and assessment }\end{array}$ \\
\hline Role of student & Receptive mind; collaborative tasks; teamwork initiatives; active commitment \\
\hline $\begin{array}{l}\text { Company's } \\
\text { incentives }\end{array}$ & $\begin{array}{l}\text { Opportunity for companies to benefit from the expertise in the HEI and adapt the students' } \\
\text { curriculum to better fit their business needs }\end{array}$ \\
\hline HEI's incentive & $\begin{array}{l}\text { Improve the employability rates of its alumni and enhance the reputation of the institution. } \\
\text { Moreover, the specialization in certain areas of knowledge will allow a differentiation with } \\
\text { respect to other universities. }\end{array}$ \\
\hline $\begin{array}{l}\text { Student' } \\
\text { incentives }\end{array}$ & $\begin{array}{l}\text { Career development; progressive skill acquisition; professional interaction and integration; } \\
\text { entrepreneurial literacy; workforce preparedness }\end{array}$ \\
\hline Duration & $\begin{array}{l}\text { Full- or part-time worker; one or several time periods during training and in one or various } \\
\text { companies }\end{array}$ \\
\hline $\begin{array}{l}\text { Obligatory } \\
\text { nature }\end{array}$ & $\begin{array}{l}\text { Optional (e.g., industrial advisory board) and mandatory (e.g., dual vocational education } \\
\text { training) }\end{array}$ \\
\hline $\begin{array}{l}\text { Monetary } \\
\text { compensation }\end{array}$ & $\begin{array}{l}\text { Companies pay students a salary or scholarship. Advisory board also receives } \\
\text { remuneration }\end{array}$ \\
\hline $\begin{array}{l}\text { Territorial } \\
\text { scope }\end{array}$ & International; national; regional; local level \\
\hline $\begin{array}{l}\text { Additional } \\
\text { supporter }\end{array}$ & Government and social partners \\
\hline $\begin{array}{l}\text { Legal HEI } \\
\text { status }\end{array}$ & Privates and public universities \\
\hline
\end{tabular}


Table A2. Key features for the category of models based on real-life teaching-learning processes (RLTLPs).

\begin{tabular}{|c|c|}
\hline Feature & Description \\
\hline $\begin{array}{l}\text { Main } \\
\text { educational } \\
\text { purposes }\end{array}$ & $\begin{array}{l}\text { - Integration of realistic, novel and updated practical concepts into the theoretical } \\
\text { classes sessions } \\
\text { - } \quad \text { Professional development } \\
\text { - } \quad \text { Professional socialization } \\
\text { - } \quad \text { Promote applied research at the university level }\end{array}$ \\
\hline $\begin{array}{l}\text { Role of } \\
\text { company }\end{array}$ & $\begin{array}{ll}\text { - } & \text { Supervision and evaluation } \\
\text { - } & \text { Propose applied research contents } \\
\text { - } & \text { Integration of employees within the academic community }\end{array}$ \\
\hline Role of HEI & $\begin{array}{l}\text { - } \quad \text { Set learning objectives and teaching units within the selected subjects } \\
\text { - } \quad \text { Approval of host location and work staff } \\
\text { - } \quad \text { Participation in the selection of the student or researcher } \\
\text { - } \quad \text { Incorporation of employees into the academic community }\end{array}$ \\
\hline Role of student & $\begin{array}{l}\text { - Full or part-time regardless of their engagement in productive work. Students may be } \\
\text { observers (visiting professor sessions) or actively participate in tasks (summer schools } \\
\text { and PhD programmes) }\end{array}$ \\
\hline $\begin{array}{l}\text { Company's } \\
\text { incentives }\end{array}$ & $\begin{array}{l}\text { Access to highly skilled workers and the most recent research advances and the possibility } \\
\text { of having their employees bring their professional activity closer to the classroom }\end{array}$ \\
\hline $\begin{array}{l}\text { HEI's } \\
\text { incentives }\end{array}$ & $\begin{array}{l}\text { - } \quad \text { Build long-lasting partnerships with companies of benefit to all parties } \\
\text { - } \quad \text { gaise awareness of the added value of academic research for industry and society in } \\
\text { - Help to improve recognition of the doctoral degree and give it a more applied profile } \\
\text { - } \quad \text { Ensure that PhD students are aware of all professional opportunities and are thus able } \\
\text { to adapt their academic training and research to the job market. }\end{array}$ \\
\hline $\begin{array}{l}\text { Student's } \\
\text { incentives }\end{array}$ & $\begin{array}{l}\text { - Exposure to non-university environments even without leaving the classroom } \\
\text { - } \quad \text { Improved ability to apply abstract concepts in real work settings }\end{array}$ \\
\hline Duration & Short-term (1-3 days); medium-term (1 semester); long-term (one year or more) \\
\hline $\begin{array}{l}\text { Obligatory } \\
\text { nature }\end{array}$ & Optional \\
\hline $\begin{array}{l}\text { Monetary } \\
\text { compensation }\end{array}$ & $\begin{array}{l}\text { Either remunerated or on a voluntary basis. In some cases, the student has to pay for it } \\
\text { (summer schools) }\end{array}$ \\
\hline $\begin{array}{l}\text { Territorial } \\
\text { scope }\end{array}$ & International; national; regional; local \\
\hline $\begin{array}{l}\text { Additional } \\
\text { supporter }\end{array}$ & Business and professional associations; labour and trade unions \\
\hline $\begin{array}{l}\text { Legal HEI } \\
\text { status }\end{array}$ & Both, although private universities are more likely to favour these types of models \\
\hline
\end{tabular}


Table A3. Key features for the category of models based on approaches of working life to students (AWL2SS).

\begin{tabular}{|c|c|}
\hline Feature & Description \\
\hline $\begin{array}{l}\text { Main } \\
\text { educational } \\
\text { purposes }\end{array}$ & $\begin{array}{l}\text { - Development of transversal skills, such as CV design, personal interviews, ability to } \\
\text { work in a team and adaptability to new situations; } \\
\text { - Improved social skills } \\
\text { - } \quad \text { Ability to transfer practical knowledge and implement it locally }\end{array}$ \\
\hline $\begin{array}{l}\text { Role of } \\
\text { company }\end{array}$ & $\begin{array}{l}\text { - Joint proposal (university-business) for dissemination activities } \\
\text { - } \quad \text { Active involvement in external activities } \\
\text { - } \quad \text { Mentoring, supervision and evaluation } \\
\text { proposing activities that are not necessarily close to real industrial activities, but that } \\
\text { of work }\end{array}$ \\
\hline Role of HEI & $\begin{array}{l}\text { - Joint proposal (university-business) for dissemination activities } \\
\text { - } \quad \text { Dissemination and making technical and teaching resources available to students } \\
\text { - } \quad \text { Set host site and assist with student selection }\end{array}$ \\
\hline Role of student & $\begin{array}{l}\text { May be observer or passive receiver (career fairs, mentoring programmes) or actively } \\
\text { participate in activities (competitions) }\end{array}$ \\
\hline $\begin{array}{l}\text { Company's } \\
\text { incentives }\end{array}$ & $\begin{array}{l}\text { - Disseminate the activities and business lines of the company } \\
\text { - } \quad \text { Ability to influence students' decision making based on the company's work needs } \\
\text { - Access to highly skilled employees }\end{array}$ \\
\hline $\begin{array}{l}\text { HEI's } \\
\text { incentives }\end{array}$ & $\begin{array}{l}\text { - } \quad \text { Build long-lasting partnerships with companies of benefit to all parties } \\
\text { Raise awareness of the added value of academic research for the industry and society } \\
\text { in general }\end{array}$ \\
\hline $\begin{array}{l}\text { Student's } \\
\text { incentives }\end{array}$ & $\begin{array}{l}\text { - } \quad \text { Exposure to non-academic environments } \\
\text { - } \quad \text { Get closer to the job offer available in a certain geographical area } \\
\text { - } \quad \text { Improved ability to apply abstract concepts in practical work settings } \\
\text { Develop transversal skills }\end{array}$ \\
\hline Duration & Short-term (1-3 days); medium-term (1 semester); long-term (one year or more) \\
\hline $\begin{array}{l}\text { Obligatory } \\
\text { nature }\end{array}$ & Optional \\
\hline $\begin{array}{l}\text { Monetary } \\
\text { compensation }\end{array}$ & $\begin{array}{l}\text { There is normally no remuneration, with the exception of some models where there may be } \\
\text { incentives in kind and competition prizes, which could be in cash but also in the form of } \\
\text { payment for higher training courses }\end{array}$ \\
\hline $\begin{array}{l}\text { Territorial } \\
\text { scope }\end{array}$ & International; national; regional; local \\
\hline $\begin{array}{l}\text { Additional } \\
\text { Supporter }\end{array}$ & Business and professional associations \\
\hline $\begin{array}{l}\text { Legal HEI } \\
\text { status }\end{array}$ & Both, although private universities are more likely to favour these types of models \\
\hline
\end{tabular}


Table A4. Key features for the category of models based on sponsorship initiatives by companies (SICs).

\begin{tabular}{|c|c|}
\hline Feature & Description \\
\hline $\begin{array}{l}\text { Main } \\
\text { educational } \\
\text { purposes }\end{array}$ & $\begin{array}{l}\text { Enhancement of students' skills applied to company strategies and contribution to the } \\
\text { convergence of R\&D in the HEI and the industry. }\end{array}$ \\
\hline $\begin{array}{l}\text { Role of } \\
\text { company }\end{array}$ & Finance the initiatives and commitment to bring qualified students into their business \\
\hline Role of HEI & Evaluation and management of R\&D installations and resources \\
\hline Role of student & Career development and workforce preparedness \\
\hline $\begin{array}{l}\text { Company's } \\
\text { incentives }\end{array}$ & $\begin{array}{l}\text { - Have an employment pool made up of trained workers according to the realistic } \\
\text { needs of the company } \\
\text { - Have external research staff available }\end{array}$ \\
\hline $\begin{array}{l}\text { HEI's } \\
\text { incentives }\end{array}$ & $\begin{array}{l}\text { Availability of funding resources and incorporate in its community highly skilled students } \\
\text { and researchers }\end{array}$ \\
\hline $\begin{array}{l}\text { Student's } \\
\text { incentives }\end{array}$ & $\begin{array}{l}\text { Option of continuing their studies in a highly specialized work environment, in line with } \\
\text { company interests and future job insertion }\end{array}$ \\
\hline Duration & $\begin{array}{l}\text { Medium-term (12-24 months) in the case of a student grant and long-term (several years) } \\
\text { when the work is sponsored by laboratories }\end{array}$ \\
\hline $\begin{array}{l}\text { Obligatory } \\
\text { nature }\end{array}$ & Optional \\
\hline $\begin{array}{l}\text { Monetary } \\
\text { compensation }\end{array}$ & $\begin{array}{l}\text { No compensation unless the salary of the trainee/researcher is financed by a laboratory } \\
\text { sponsorship.In the case of students, the financial compensation is indirect, since a } \\
\text { scholarship means savings for the student }\end{array}$ \\
\hline $\begin{array}{l}\text { Territorial } \\
\text { scope }\end{array}$ & National/International \\
\hline $\begin{array}{l}\text { Additional } \\
\text { supporter }\end{array}$ & Government, through programmes that provide incentives to companies \\
\hline $\begin{array}{l}\text { Legal HEI } \\
\text { status }\end{array}$ & In both, but the private ones prevail \\
\hline
\end{tabular}

\section{References}

1. DeCoito, I. Developing integrated science, technology, engineering and mathematics (STEM) projects in education. In Proceedings of the 7th International Conference Engineering Education for Sustainable Development, Vancouver, BC, Canada, 9-12 June 2015.

2. Grosemans, I.; Coertjens, L.; Kyndt, E. Exploring learning and fit in the transition from higher education to the labour market: A systematic review. Educ. Res. Rev. 2017, 21, 67-84. [CrossRef]

3. Jamaluddin, N.; Ayob, A.; Osman, S.A.; Kofli, N.T.; Johar, S. Undergraduate industrial training experience: A win-win situation for students, industry and faculty. Procedia Soc. Behav. Sci. 2013, 102, 648-653. [CrossRef]

4. Skute, I.; Zalewska-Kurek, K.; Hatak, I.; de Weerd-Nederhof, P. Mapping the field: A bibliometric analysis of the literature on university-industry collaborations. J. Technol. Transf. 2017, 44, 916-947. [CrossRef]

5. Edmondson, G.; Valigra, L.; Kenward, M.; Hudson, R.L.; Belfield, H. Making Industry-University Partnerships Work: Lessons from Successful Collaborations; Science Business Innovation Board AISBL: Brussels, Belgium, 2012.

6. Dima, A.M.; Hadad, S.; Luchian, I. Review on the dimensions of business-university alliances. Proc. Int. Conf. Bus. Excell 2017, 11, 64-73. [CrossRef]

7. González, R.; Batanero, F. A review of problem-based learning applied to engineering. EduRe J. Int. J. Adv. Educ. Res. 2016, 3, 2340-2504.

8. Martínez, R.; del Carmen, M.; de la Rosa, D. Motivation in university students under problem based learning. Differences in academic results from an extraordinary call for exam. EduRe J. Int. J. Adv. Educ. Res. 2015, 2, 2340-2504. 
9. Warnock, J.N.; Mohammadi-Aragh, M.J. Case study: Use of problem-based learning to develop students technical and professional skills. Eur. J. Eng. Educ. 2016, 41, 142-153. [CrossRef]

10. Mascarenhas, C.; Ferreira, J.J.; Marques, C. University-industry cooperation: A systematic literature review and research agenda. Sci. Public Policy 2018, 45, 1-11. [CrossRef]

11. Schuster, L.; Glavas, C. Exploring the dimensions of electronic work integrated learning (eWIL). Educ. Res. Rev. 2017, 21, 55-66. [CrossRef]

12. Goel, R.K.; Göktepe-Hultén, D.; Grimpe, C. Who instigates university-industry collaborations? University scientists versus firm employees. Small Bus. Econ. 2017, 48, 503-524. [CrossRef]

13. Cord, B.; Clements, M.D. Early Organizational Involvement (EOI): Creating Successful Transitions from Higher Education to the Work Place. Dev. Learn. Organ. Int. J. 2010, 3, 5-7. [CrossRef]

14. National Principles and Operational Guidelines for Recognition of Prior Learning; National Framework of Qualifications: Sydney, Australia, 2007.

15. Clayton, B.; Blom, K.; Bateman, A.; Bedggood, M.; Hughes, E. What's in It for Me? Recognition of Prior Learning in Enterprise-Based Registered Training Organisations. Australian National Training Authority. National Centre for Vocational Education Research (NCVER). 2004. Available online: www.ncver.edu.au (accessed on 10 September 2020).

16. Sheridan, I.; Linehan, M. Work Placement in Third-Level Programmes. In Roadmap for Employment-Academic Partnerships; Dublin Institute of Technology: Dublin, Ireland, 2011.

17. Thune, T. Success factors in higher education-industry collaboration: A case study of collaboration in the engineering field. Tert. Educ. Manag. 2011, 17, 31-50. [CrossRef]

18. LLLP Erasmus Multilateral Project. Reshaped Partnerships for Competitiveness and Innovation Potential (RePCI) in Mechanical Engineering. 2013-2015(540425-LLP-1-2013-1-FI-ERASMUS-EKA). Available online: https: //eacea.ec.europa.eu/sites/eacea-site/files/documents/compendium-final.pdf (accessed on 10 September 2020).

19. HEIBus Project. Available online: http://heibus.eu (accessed on 10 September 2020).

20. European Commission. Youth on the Move. A Europe 2020 Initiative. 2015. Available online: http://ec.europa.eu/ youthonthemove/index_en.htm (accessed on 10 August 2020).

21. European Commission. An Agenda for New Skills and Jobs: A European Contribution towards Full Employment $\operatorname{COM(2010)} 682$ Final; European Commission: Strasbourg, France, 2010; pp. 1-21.

22. European Commission. Innovation Union—Research and Innovation. 2018. Available online: https://ec.europa. eu/info/research-and-innovation/strategy/goals-research-and-innovation-policy/innovation-union_en (accessed on 10 August 2020).

23. Pertuze, J.A.; Calder, E.S.; Greitzer, E.M.; Lucas, W.A. Best practices for industry-university collaboration. MIT Sloan Manag. Rev. 2010, 51, 83-90.

24. Roshani, M.; Lehoux, N.; Frayret, J.M. University-Industry collaborations and open innovations: An integrated methodology for mutually beneficial relationships. In Proceedings of the CIRRELT Conference, Montreal, QC, Canada, 16-17 May 2015.

25. Schartinger, D.; Rammer, C.; Fischer, M.; Frohlich, J. Knowledge interactions between universities and industry in Austria: Sectoral patterns and determinants. Res. Policy 2002, 31, 303-328. [CrossRef]

26. Chesbrough, H.W. Open innovation: The new imperative for creating and profiting from technology. Res. Policy 2005, 4, 122-123.

27. Borrego, M.; Foster, M.J.; Froyd, J.E. Systematic literature reviews in engineering education and other developing interdisciplinary fields. J. Eng. Educ. 2018, 103, 45-76. [CrossRef]

28. Satty, T.L. The Analytic Hierarchy Process; McGraw-Hill: New York, NY, USA, 1980.

29. Bremner, D.; Meehan, K.; Liu, Y.; Liu, X. Creating a university-industry advisory board for a joint engineering school. In Proceedings of the ASEE Annual Conference \& Exposition, New Orleans, LA, USA, 26-29 June 2016.

30. Pugh, S.L.; Grove, M.J. Establishing industrial advisory boards using a practice transfer model. New Dir. High. Educ. Acad. 2014, 10, 20-25.

31. The University of Sydney; Industry Advisory Board; Faculty of Engineering and Information Technologies. 2018. Available online: https://sydney.edu.au/engineering/about/school-of-computer-science/industryadvisory-board.html (accessed on 10 August 2020).

32. Oklahoma, T.U.; Gallogly College of Engineering. Industrial \& Systems Engineering. 2019. Available online: https://www.ou.edu/coe/ise (accessed on 10 September 2020). 
33. The University of Manchester; Industry Club; School of Computer Science. 2019. Available online: https://www.cs.manchester.ac.uk/industry/club/ (accessed on 10 September 2020).

34. The University of Toledo; Engineering Technology. Industrial Advisory Boards. 2019. Available online: https://www.utoledo.edu/engineering/engineering-technology/iab.html (accessed on 10 September 2020).

35. Genheimer, S.R.; Shehab, R. The effective industry advisory board in engineering education-A model and case study. In Proceedings of the 37th Annual Frontiers in Education Conference-Global Engineering: Knowledge Without Borders, Opportunities Without Passports, Milwaukee, WI, USA, 10-13 October 2007; pp. T3E-6-T3E-12.

36. ABET. The Accreditation Board for Engineering and Technology (ABET). 2018. Available online: http: //www.abet.org/ (accessed on 10 August 2020).

37. Froyd, J.E.; Wankat, P.C.; Smith, K.A. Five major shifts in 100 years of engineering education. Proc. IEEE 2012, 100, 1344-1360. [CrossRef]

38. ILO. Compilation of Assessment Studies on Technical Vocational Education and Training (TVET); ILO Regional Skills Programme: Bangkok, Thailand, 2016.

39. Dualvet Project. Dual Vocational Education Training. 2015. Available online: http://www.dualvet.eu/ (accessed on 10 August 2020).

40. German Office for International Cooperation in Vocational Education and Training (GOVET). In Presentations on Dual VET in Germany. 2018. Available online: www.bibb.de/govet/en/54880.php (accessed on 10 August 2020).

41. Ministry of Danish Education. Adult Education and Continuing Training. 2018. Available online: http://eng.uvm.dk/ (accessed on 10 August 2020).

42. U.S. Department of Education. 2007; U.S. Denmark Partnership for Vocational Education. Available online: https://www2.ed.gov/about/offices/list/ovae/pi/usdnmrk/dksys.html (accessed on 10 September 2020).

43. Henningsson, M.; Geschwind, L. Senior industry practitioners as part-time visiting professors: The various benefits of collaboration. High. Educ. Policy 2019, 32, 109-112. [CrossRef]

44. The Royal Academy of Engineering. Educating Engineers to drive the Innovation Economy; Cardiff University: Cardiff, UK, 2012.

45. Kong, X.; Dabney, K.P.; Tai, R.H. The association between science summer camps and career interest in science and engineering. Int. J. Sci. Educ. Part B 2014, 4, 54-65. [CrossRef]

46. Larsen, P.G.; Fernandes, J.M.; Habel, J.; Lehrskov, H.; Vos, R.J.C.; Wallington, O.; Zidek, J. A multidisciplinary engineering summer school in an industrial setting. Eur. J. Eng. Educ. 2009, 34, 511-526. [CrossRef]

47. Utrecht Summer School. Summer Schools in Europe. 2018. Available online: http://www.summerschoolsineurope. eu/ (accessed on 10 August 2020).

48. Aarhus University. 2018. Available online: http://ingenioer.au.dk/en/collaboration/ (accessed on 10 August 2020).

49. Thune, T. Doctoral students on the university-industry interface: A review of the literature. High. Educ. 2009, 58, 637-651. [CrossRef]

50. Granata, S.N.; Dochy, F. Applied PhD research in a work-based environment: An activity theory-based analysis. Stud. High. Educ. 2016, 41, 990-1007. [CrossRef]

51. Lindén, M.; Björkman, M. Experience from industrial graduate (PhD) schools. In Proceedings of the World Congress on Medical Physics and Biomedical Engineering, Prague, Czech Republic, 3-8 June 2018; pp. 731-733.

52. Sundström, A.; Widforss, G.; Rosqvist, M.; Hallin, A. Industrial PhD students and their projects. Procedia Comput. Sci. 2016, 100, 739-746. [CrossRef]

53. European University Association. Collaborative Doctoral Education: University-Industry Partnerships for Enhancing Knowledge Exchange. 2009. Available online: http://www.eua.be/activities-services/projects/ past-projects/research-and-innovation/doc-careers.aspx (accessed on 10 September 2020).

54. Technical University of Denmark; PhD Programme-CEE; Department of Electrical Engineering. 2017. Available online: http://www.cee.elektro.dtu.dk/education/phd_programme (accessed on 10 August 2020).

55. Hooley, T.; Marriott, J.; Watts, A.; Coiffait, L. Careers 2020: Options for Future Careers Work in English Schools; Pearson: London, UK, 2012.

56. Kolodinsky, P.; Schroder, V.; Montopoli, G.; McLean, S.; Mangan, P.; Pederson, W. The career fair as a vehicle for enhancing occupational self-efficacy. Prof. Sch. Couns. 2006, 10, 161-167. [CrossRef]

57. Cornell University Career Services; University Career Fair Days. 2019. Available online: http://www.career. cornell.edu/events/university_fair/ (accessed on 10 September 2020). 
58. The University of Sydney. Attend a Careers Fair-Careers Centre. 2019. Available online: http://sydney.edu. au/careers/employers/attend-a-careers-fair.html (accessed on 10 September 2020).

59. EasyVirtualFair, 2019. Easy Virtual Fair-Virtual Job Fair Software. Available online: http://www. easyvirtualfair.com/ (accessed on 10 September 2020).

60. Universidad de Málaga. V Feria Virtual de Empleo UMA Virtual Fair. 2019. Available online: https: //feriavirtualuma.easyvirtualfair.com/ (accessed on 10 September 2020).

61. Ahn, B.; Cox, M.F. Knowledge, skills, and attributes of graduate student and postdoctoral mentors in undergraduate research settings. J. Eng. Educ. 2016, 105, 605-629. [CrossRef]

62. Chun, J.U.; Sosik, J.J.; Yun, N.Y. A longitudinal study of mentor and protégé outcomes in formal mentoring relationships. J. Organ. Behav. 2012, 33, 1071-1094. [CrossRef]

63. Phillips-Jones, L. The Mentor's Guide: How to Be the Kind of Mentor You Once Had-Or Wish You'd Had; Coalition of Counseling Centers: Grass Valley, CA, USA, 2000.

64. Berlin Starup Academy. 2019. Mentors. Available online: http://berlinstartupacademy.com/mentoren-gallery (accessed on 10 September 2020).

65. Cambridge Wireless. 2019. Programmes. Available online: http://www.cambridgewireless.co.uk/ programmes/ (accessed on 10 September 2020).

66. Hubraum. The incubator of Deutsche Telekom, 2017. Mentors. Available online: https://www.hubraum. com/mentors (accessed on 10 September 2020).

67. Microsoft. Students and Grads, Microsoft Careers. 2019. Available online: https://careers.microsoft.com/us/ en/students-and-graduates (accessed on 10 September 2020).

68. King's College London. Mentoring-Role Descriptions. 2018. Available online: https://alumni.kcl.ac.uk/ alumni-benefits/mentoring/mentoring-role-descriptions (accessed on 10 August 2020).

69. The University of Manchester; School of Computer Science. Industrial Mentoring in Software Engineering. 2017. Available online: https://www.cs.manchester.ac.uk/connect/business-engagement/ industrial-mentoring/ (accessed on 10 August 2020).

70. Sqore. Student Competitions. 2018. Available online: https://studentcompetitions.com/ (accessed on 10 August 2020).

71. Collins, D.S.; Davis, G.W. Using collegiate competitions to provide an enhanced engineering education: A case study. In Proceedings of the IEEE Global Engineering Education Conference (EDUCON), Athens, Greece, 26-28 April 2017; pp. 1378-1382.

72. Worm, B.S.; Buch, S. Does competition work as a motivating factor in E-Learning? A randomized controlled trial. PLoS ONE 2014, 9, e85434. [CrossRef]

73. Xu, Y.; Wu, D.; Chen, D.; Gu, J.; Gao, L. To promote the engineering innovative abilities of undergraduates by taking projects as the guidance and competitions as the promotion. In Proceedings of the ETOP, Hangzhou, China, 28-31 May 2017; p. 1045240.

74. Sukiman, S.A.; Yusop, H.; Mokn, R.; Jaafar, H. Competition-based learning: Determining the strongest skill that can be achieved among higher education learners. In Regional Conference on Science, Technology and Social Sciences (RCSTSS 2014); Springer: Singapore, 2016; pp. 505-516.

75. Tan, N.; Mohan, R.; Foong, S.; Yamakita, M.; Iwase, M.; Hatakeyama, S.; Zhu, Q. IDC Robocon: A transnational teaming competition for project-based design education in undergraduate robotics. Robotics 2016, 5, 12. [CrossRef]

76. Navarro, I.; Gutiérrez, Á.; Montero, C.; Rodríguez-Ubiñas, E.; Matallanas, E.; Castillo-Cagigal, M.; Vega, S. Experiences and methodology in a multidisciplinary energy and architecture competition: Solar Decathlon Europe 2012. Energ. Build. 2014, 83, 3-9. [CrossRef]

77. Moto Engineering Foundation. MotoStudent. 2020. Available online: http://www.motostudent.com/ (accessed on 10 August 2020).

78. The Siemens Foundation Programs. 2017. Available online: Http://www.siemens-foundation.org/programs/ (accessed on 10 August 2020).

79. Banco Santander Fundación Universia. 2019. Doctorado. Available online: http://www.fundacionuniversia. net/seccion/becas/doctorado/ (accessed on 10 September 2020).

80. Intel. Intel Scholarship for Employees' and Retirees' Children. 2019. Available online: https://www.intel. com/content/www/us/en/employee/scholarship.html?wapkw=scholarship (accessed on 10 September 2020).

81. Yang, P.; Tao, L. Perspective: Ranking of the world's top innovation management scholars and universities. J. Prod. Innov. Manag. 2012, 29, 319-331. [CrossRef] 
82. Albahari, A.; Pérez-Canto, S.; Barge-Gil, A.; Modrego, A.A. Technology parks versus science parks: Does the university make the difference? Technol. Forecast. Soc. Chang. 2017, 16, 13-28. [CrossRef]

83. Ghent University. 2018. Tech Lane Ghent Science Park/Campus. Available online: http://www.techlane.be/ about/ (accessed on 10 September 2020).

84. IBM. The Haifa Facility of the IBM R \& D Labs in Israel. 2019. Available online: http://www.research.ibm. Com/labs/haifa/visitor.shtml (accessed on 10 September 2020).

85. Fernandes, G.; Pinto, E.B.; Araújo, M.; Magalhães, P.; Machado, R.J. A Method for measuring the success of collaborative university-industry. Funded contracts. Procedia Comput. Sci. 2017, 121, 451-460. [CrossRef]

86. InnoEnergy. InnoEnergy-pioneering change in sustainable energy. 2019. Available online: http://www. innoenergy.com/ (accessed on 10 September 2020).

C 2020 by the authors. Licensee MDPI, Basel, Switzerland. This article is an open access article distributed under the terms and conditions of the Creative Commons Attribution (CC BY) license (http://creativecommons.org/licenses/by/4.0/). 